\title{
Pelaksanaan Program Pendidikan Kecakapan Wirausaha (PKW) Pada Lembaga Pendidikan Nonformal di Kota Bandung (Studi Kasus LKP Karya Duta)
}

\author{
Soni W. Ramadhan ${ }^{1}$, Budiman Rusli ${ }^{2}$, Nina Karlina ${ }^{3}$ \\ ${ }^{1}$ Mahasiswa Magister Adminsitrasi Publik, Universitas Padjadjaran, ${ }^{2,3}$ Dosen Magister \\ Administrasi Publik, Fakultas Ilmu Sosial dan Ilmu Politik, Universitas Padjadjaran \\ 1,2,3 Jl. Bukit Dago Utara No.25, Dago, Kecamatan Coblong, Kota Bandung \\ ${ }^{1}$ soniramadhan1307@gmail.com
}

Received: 13 August 2021; Revised: 02 October 2021; Accepted: 28 December 2021 DOI: http://dx.doi.org/10.37905/aksara.8.1.595-594.2022

\begin{abstract}
The problem of low labor absorption is expected to be overcome by promoting entrepreneurship. This research was conducted with the aim of knowing the implementation of the Entrepreneurial Skills Education (PKW) program at LKP Karya Duta, Bandung. The research method used is descriptive qualitative, using program variables, implementing organizations and beneficiaries of David Korten's Policy Implementation Model. Data collection techniques using observation and interviews. Determination of informants using purposive sampling consisting of program coordinators, managers of educational institutions, students and instructors. The results of the study show that this program is very useful in helping people of productive age who do not work to gain knowledge, increase competence and have the opportunity to start independent businesses which are supported by the readiness of LKP Karya Duta in the implementation process.
\end{abstract}

Keyword : implementasi, entrepreneurship, business startup, competency.

\begin{abstract}
Abstrak
Permasalahan rendahnya keterserapan tenaga kerja diharapkan dapat diatasi dengan menggalakkan wirausaha. Penelitian ini dilakukan dengan tujuan untuk mengetahui pelaksanaan program Pendidikan Kecakapan Wirausaha (PKW) di LKP Karya Duta, Bandung. Metode penelitian yang digunakan adalah kualitatif deskriptif, menggunakan variabel program, organisasi pelaksana serta penerima manfaat dari Model Implementasi Kebijakan David Korten. Teknik pengumpulan data menggunakan observasi dan wawancara. Penentuan informan menggunakan purposive sampling terdiri dari koordinator program, pengelola lembaga pendidikan, peserta didik beserta instruktur. Hasil penelitian menunujukkan bahwa program ini sangat bermanfaat dalam membantu masyarakat usia produktif yang tidak bekerja untuk memperoleh ilmu, meningkatkan kompetensi serta adanya kesempatan merintis usaha mandiri yang didukung dengan kesiapan LKP Karya Duta dalam proses pelaksanaan.
\end{abstract}

Kata Kunci : pelaksanaan, wirausaha, rintisan usaha, kompetensi. 


\section{PENDAHULUAN}

Masalah keterserapan tenaga kerja oleh dunia industri dan dunia kerja selalu menjadi permasalahan dan menuntut perhatian pemerintah. Setiap tahunnya angka lulusan sekolah menengah atas maupun kejuruan selalu meningkat. Pada rentang usia ini mereka mulai terhitung sebagai penduduk usia produktif, yang menurut BPS, dimulai dari usia 15 tahun. Namun hal ini tidak dibarengi dengan bertambahnya jumlah lowongan pekerjaan.

Data dari Badan Pusat Statistik (BPS), populasi warga negara Indonesia pada 2019 mencapai 270 juta jiwa, mengalami peningkatan sebanyak 32,5 juta jiwa dari tahun 2010 atau naik sebesar 14. 46 persen. Proporsi jumlah penduduk usia produktif (usia 15-65 tahun) sebanyak kurang lebih 183,36 juta jiwa atau sekitar 68,7 persen dari total keseluruhan populasi. Sedangkan pada tahun 2020 jumlah penduduk bekerja meningkat menjadi 131 juta jiwa dengan jumlah penduduk menganggur dan tidak terserap oleh dunia kerja sebanyak 6,8 juta jiwa naik $0.06 \%$ dibanding periode yang sama tahun lalu.

Sementara kondisi di lapagan sendiri, terdapat jumlah anak putus sekolah (drop out) di tingkat pendidikan menengah, atas dan sederajat yang mengalami peningkatan dari jumlah tahun 2018 sebanyak 22,15\% menjadi 24,28\% pada tahun 2020 (BPS, 2020). Keadaan ini tentu sedikit banyak menjadi beban tersendiri bagi pemerintah. Dengan banyaknya jumlah penganggur ditambah masyarakat usia produktif yang menyelesaikan pendidikan dan tidak melanjutkan ke jenjang yang lebih tinggi dapat berdampak pada munculnya permasalahan sosial seperti kejahatan, penyalahgunaan narkoba, pergaulan bebas dan terutama lemahnya daya saing bangsa.

Salah satu upaya pemerintah dalam mencari solusi masalah keterserapan tenaga kerja yang rendah ini diantaranya adalah dengan mengembangkan lebih banyak programprogram kewirausahaan melalui kementerian/lembaga/dinas terkait. Cara ini dipandang lebih efektif dan efisien karena akan dapat dilaksanakan langsung oleh pemerintah maupun pemerintah daerah yang akan bersentuhan langsung dengan masyarakat.

Kewirausahaan sendiri umumnya bersifat konstan, kontribusi bagi negara adalah meningkatkan produktivitas dengan aktivitas seperti inovasi, Baumol dalam (Minniti, 2008). Maka dari itu pemerintah merancang strategi jangka panjang dalam mengembangkan kewirausahaan ini dengan salah satu caranya adalah memajukan sumber daya manusia (SDM) melalui kegiatan pelatihan. SDM menjadi kunci dari pengembangan bisnis yang inklusif. Sementara itu menurut (Agustina, 2015) dalam upaya meningkatkan kesejahteraan dan kualitas hidup masyarakat, pemerintah harus membantu masyarakat untuk meningkatkan kualitas perekonomian, meningkatkan pendapatan per kapita, mengalokasikan sumberdaya-sumberdaya yang dimiliki negara dengan efektif dan efisien. Peningkatan jumlah kewirausahaan dalam negeri dapat memberikan solusi terkait angka pengangguran karena dapat membuka lapangan kerja sehingga meningkatkan produktivitas di lingkungannya, selain itu secara tidak langsung akan meningkatkan pendapatan per kapita, adanya alih teknologi, transfer ilmu manajemen dan sumber daya yang dimiliki.

Sebagai salah satu negara berkembang dengan jumlah penduduk yang cukup besar, Indonesia memiliki potensi Kewirausahaan yang cukup besar. Menurut data dari Kementerian Koperasi dan UMKM Indonesia potensi kewirausahaan ini memiliki dampak yang positif terhadap tingkat Gross Domestic Product (GDP) negara Indonesia. Artinya, sector kewirausahaan memiliki kontribusi yang signifikan dalam pengembangan 
AKSARA: Jurnal Ilmu Pendidikan Nonformal

P-ISSN 2407-8018 E-ISSN 2721-7310 DOI prefix 10.37905

Volume 08, (1), January 2022

http://ejurnal.pps.ung.ac.id/index.php/Aksara

perekonomian suatu negara. Selain itu juga terdapat data bahwa ada peningkatan rasio wirausaha dari $1,67 \%$ meningkat menjadi $3,10 \%$ atau sebanyak 8.06 juta jiwa pada tahun 2018 dan pada 2020 ini sudah berada di angka 3.47\% (Ulya, 2020). Pemerintah sendiri memiliki target mencetak sebanyak $3.99 \%$ dari penduduk Indonesia berwirausaha pada tahun 2024.

Dalam A Road Map To Vocational Education and Training in Industrialized Countries ketidakterserapan tenaga produktif ini juga terjadi di negara-negara maju benua Eropa (Eichhorst, Rodriguez-Planas, Schmidl, \& Zimmermann, 2015). Dalam Organization for Economic Cooperation and Development (OECD) tahun 2013 disebutkan bahwa penduduk usia produktif di negara Eropa seperti Portugal, Italia, Spanyol dan Yunani mengalami kesulitan untuk memiliki penghasilan antara lain disebabkan karena kurangnya kompetensi yang dimiliki. Jalan keluar dari permasalahan ini adalah dengan menguatkan peran dari pendidikan vokasi atau yang dikenal dengan vocational education and training (VET).

Penguatan peran pendidikan vokasi sebagai jalan keluar dari rendahnya keterserapan tenaga kerja juga disetujui oleh Onstenk (2003) dalam Entrepreneurship and Vocational Education menunjukkan beberapa poin penting diantaranya mengenai perlunya campur tangan pemerintah dalam pengembangan program pendidikan vokasi. Dalam artikel ini juga menyebutkan bahwa belajar dengan menggunakan metode praktik adalah salah satu wujud keberhasilan dari tujuan pendidikan vokasi yaitu mencetak para wirausahawan. Pengalaman kerja bisa didapat oleh peserta didik selama menempuh proses pembelajaran (Onstenk, 2003). Meskipun penelitian dilakukan di Belanda, akan tetapi terdapat benang merah tentang pengelolaan pendidikan kewirausahaan dalam pendidikan vokasi di Indonesia, yaitu diperlukan adanya campur tangan pemerintah.

Pemerintah Indonesia melalui Peraturan Presiden No 82 tahun 2019 tentang Kementerian Pendidikan dan Kebudayaan, yang didalamnya mengatur tentang pembentukan Direktorat Jenderal Pendidikan Vokasi, berupaya memperkuat penyelenggaraan fungsi perumusan kebijakan bidang pendidikan vokasi, kejuruan dan pendidikan dan keterampilan kerja. Dengan harapan pendidikan berbasis vokasi akan lebih bisa mendapat perhatian dan berperan besar dalam pembangunan perekonomian. Selain itu juga agar sasaran yang menjadi focus perhatian akan dapat terakomodasi dengan baik sesuai dengan keadaan dan peminatan masing-masing. Pendidikan vokasi dapat diartikan merupakan turunan atau derivasi dari kebutuhan dalam dunia kerja (Miller, 1985).

Pendidikan vokasi sendiri menurut Undang-undang No 20 Tahun 2003 tentang Sistem Pendidikan Nasional ( UU Sisdiknas) dalam pasal 15 adalah merupakan pendidikan yang mempersiapkan peserta didik untuk memiliki pekerjaan dengan keahlian terapan tertentu maksimal setara dengan program sarjana. Pendidikan vokasi sendiri dapat ditempuh melalui dua jalur pilihan, yakni melalui jalur formal dan non formal.

Menurut Peraturan Pemerintah (PP) No 17 Tahun 2010 tentang Pengelolaan dan Penyelenggaraan Pendidikan pada pasal 1 ayat 6, jalur pendidikan formal ini memiliki jenjang pendidikan yang jelas, dari dasar, menengah hingga akhir. Jalur formal ini yang paling umum dan banyak ditempuh di Indonesia. Dalam hal pendidikan vokasi, jalur formal dapat ditempuh melalui Sekolah Menengah Kejuruan (SMK) di tingkat menengah, atau melalui Akademi, Politeknik, Akademi Komunitas dan Perguruan Tinggi yang menyelenggarakan pendidikan vokasi di tingkat lanjutan.

AKSARA: Jurnal Ilmu Pendidikan Nonformal 
Selain melalui jalur formal, pendidikan vokasi juga bisa ditempuh melalui jalur pendidikan nonformal. Dalam PP No 17 Tahun 2010, pendidikan nonformal adalah pendidikan yang diselenggarakan di luar pendidikan formal yang berfungsi menambah, mengganti dan melengkapi pendidikan formal. Menurut (Coombs \& Manzoor, 1985) pendidikan non-formal adalah setiap kegiatan pendidikan yang terorganisir yang diselenggarakan di luar sistem formal, baik tersendiri maupun merupakan bagian dari suatu kegiatan yang luas, yang dimaksudkan untuk memberikan layanan kepada sasaran didik tertentu dalam mencapai tujuan-tujuan belajar. Adapun lembaganya seperti lembaga kursus dan pelatihan (LKP), Pusat Kegiatan Belajar Masyarakat (PKBM), Majelis Taklim dan lain-lain.

Salah satu bentuk perhatian pemerintah dalam bidang pendidikan vokasi adalah dengan memberikan bantuan pendidikan sebagai upaya peningkatan kompetensi peserta didik dalam rangka pengembangan potensi kewirausahaan, yaitu melalui program bantuan Pendidikan Kecakapan Wirausaha (PKW). Adapaun konsep dari program PKW ini sendiri adalah pemberian bantuan dana dari pemerintah kepada lembaga pendidikan vokasi yang memiliki ikatan kerjasama dengan dunia usaha, yang akan digunakan untuk memberikan pelatihan dan membelajarkan keahlian tertentu kepada masyarakat usia produktif. Tujuannya adalah untuk memberikan bekal pengetahuan, keterampilan, sikap dan pola pikir berwirausaha melalui pelatihan yang sesuai dengan kebutuhan pasar, serta memotivasi dan menciptakan rintisan usaha baru termasuk didalamnya pendampingan untuk dapat berkembang dan mampu bermitra dengan Usaha Mikro Kecil dan Menengah (UMKM)/Dunia Usaha, Permodalan, dan pemasaran.

Berdasarkan uraian tersebut diatas dapat terlihat bahwa upaya pemerintah ini menarik untuk diulas lebih dalam di antaranya mengenai pelaksanaan program PKW pada lembaga pendidikan nonformal yaitu LKP Karya Duta yang berlokasi di Kota Bandung Provinsi Jawa Barat.

\section{METODE}

Metode yang akan digunakan dalam penelitian ini adalah deskriptif dengan menggunakan pendekatan kualitatif karena dilakukan pada kondisi alamiah atau apa adanya.

Penelitian kualitatif merupakan penelitian interpretive artinya peneliti terlibat dalam pengalaman yang berkelanjutan dan terus menerus dengan para partisipan. Keterlibatan ini nantinya diharapkan akan memunculkan serangkaian isu strategis, etis dan personal dalam proses penelitian (Creswell, 2019).

Observasi akan dilakukan dengan peneliti memposisikan diri sebagai observer dengan mengajukan pertanyaan semi-structured yang disusun berdasarkan rasa ingn tahu dan informasi awal yang diterima (Creswell, 2019).

Pemilihan partisipan yang digunakan dalam penelitian ini adalah dengan purposive sampling, yaitu partisipan yang dipilih secara sengaja atau menunjuk langsung kepada orang yang diinginkan peneliti dalam pertimbangan bahwa informan yang dipilih dianggap paling tahu tentang apa yang diharapkan (Creswell, 2019). Sumber data yang akan diambil diperoleh dari phak yang terlibat langsung dengan penyelenggaraan program Pendidikan Kecakapan Wirausaha di Kota Bandung, yaitu pengelola lembaga, instruktur, dan peserta didik.

598 AKSARA: Jurnal Ilmu Pendidikan Nonformal 
Dalam penelitian ini yang akan diteliti adalah 8 orang yang peneliti anggap terlibat langsung dalam implementasi program Pendidikan Kecakapan Wirausaha ini terdiri dari Koordinator Program Pendidikan Kecakapan Wirausaha dari Direktorat Kursus dan Pelatihan, Pimpinan lembaga pendidikan penyelenggara program, instruktur, serta peserta didik. Lembaga yang dijadikan sebagai sample adalah Lembaga Kursus dan Pelatihan (LKP) Karya Duta Bandung

\section{HASIL DAN PEMBAHASAN Implementasi Kebijakan}

Implementasi kebijakan sendiri merupakan suatu cara mentransformasikan kegiatan atau program dalam suatu kegiatan untuk dapat mencapai perubahan atau tujuan yang diinginkan. Dari tujuan yang dinginkan tersebut kemudian semua kegiatan di implementasikan dan dinilai apakah termasuk dalam kategori baik, sedang, atau mungkin gagal dalam mencapai tujuan.

Sedangkan (Van Meter \& Van Horn, 1975) menyatakan, "Implementasi kebijakan meliputi tindakan tindakan oleh individu umum maupun pribadi atau kelompok yang diarahkan pada pencapaian tujuan yang ditetapkan dalam keputusan kebijakan sebelumnya."

Jadi, implementasi kebijakan merupakan tindakan yang dilakukan pemerintah dan swasta baik secara individu maupun kelompok untuk mencapai tujuannya (Wibawa, 2002).

Sedangkan mengenai implementasi program sendiri menurut (Westra, 1989) adalah "rumusan yang memuat gambaran pekerjaan yang akan dilaksanakan yang didalamnya berisi mengenai petunjuk dan cara pelaksanaan". Melalui program maka segala bentuk rencana dalam kebijakan akan lebih terorganisir dan lebih mudah untuk dilaksanakan. Solichin dalam (Jones, 1994) berpendapat bahwa program adalah unsur pertama yang harus ada demi terciptanya suatu kegiatan.

Dalam perspektif ini apabila dikaitkan dengan implementasi Program Pendidikan Kecakapan Wirausaha (PKW) yang telah disahkan dalam Peraturan Direktorat Jenderal Pendidikan Vokasi Nomor 2 tahun 2020 tentang Petunjuk Teknis Bantuan Pemerintah Program Pendidikan Kecakapan Wirausaha (PKW) yang didalamnya mengatur mengenai tata cara pelaksanaan dan petunjuk teknis pemberian bantuan pemerintah dalam bidang pendidikan vokasi maka dapat dilihat sebenarnya telah ada dasar hukum yang jelas mengenai ketentuan-ketentuan serta tujuan yang ingin dicapai dari pelaksanaan program ini. Peraturan Direktorat Jenderal Pendidikan Vokasi ini sendiri merupakan turunan dari Undang-undang Nomor 20 tahun 2003 tentang Sistem Pendidikan Nasional dan beberapa peraturan pemerintah diantaranya Peraturan Pemerintah Nomor 48 Tahun 2005 tentang Pendanaan Pendidikan, Peraturan Pemerintah Nomor 31 Tahun 2006 tentang Sistem Pelatihan Kerja Nasional, Peraturan Pemerintah Nomor 17 Tahun 2010 tentang Pengelolaan dan Penyelenggaraan Pendidikan serta Peraturan Menteri Pendidikan dan Kebudayaan Nomor 32 Tahun 2019 tentang Pedoman Umum Penyaluran Bantuan Pemerintah di Lingkungan Kementerian Pendidikan dan Kebudayaan.

\section{Pelaksanaan Program Pendidikan Kecakapan Wirausaha}

Pada tahun 2020 ini pelaksanaan program PKW berada di bawah Direktorat Jenderal Pendidikan Vokasi, dengan berlandaskan pada Peraturan Direktorat Jenderal 
Pendidikan Vokasi (Perdirjen Vokasi) No 02 Tahun 2020 tentang Petunjuk Teknis Bantuan Pemerintah Program Pendidikan Kecakapan Wirausaha (PKW) Tahun 2020. Adapun untuk teknis penyaluran bantuan mengacu pada Peraturan Menteri Pendidikan dan Kebudayaan No 32 Tahun 2019 tentang Pedoman Umum Penyaluran Bantuan Pemerintah di Lingkungan Kementerian Pendidikan dan Kebudayaan. Diantaranya, tujuan pemberian bantuan untuk pengembangan kapasitas dan kemampuan individu (pasal 1 huruf a), penerima bantuan adalah lembaga pendidikan (pasal 3 ayat 4), jenis bantuan yang dibolehkan diantaranya berbentuk beasiswa atau bantuan dana (pasal 5 huruf b). Selaku pemberi bantuan adalah Direktorat Kursus dan Pelatihan yang merupakan salah satu direktorat yang berada di bawah naungan Direktorat Jenderal Pendidikan Vokasi (Direktorat Kursus dan Pelatihan, 2020). Alokasi dana sendiri yang disalurkan melalui Daftar Isian Pelaksanaan Anggaran Direktorat Kursus Tahun 2020 ditentukan sebesar Rp 6.000.000 per peserta didik. Penggunaan anggaran dimaksud sebagaimana tercantum terbagi menjadi Manajemen 10\%, Biaya Pembelajaran, Evaluasi dan Pendampingan 40\% dan sisanya digunakan sebagai stimulan rintisan usaha.

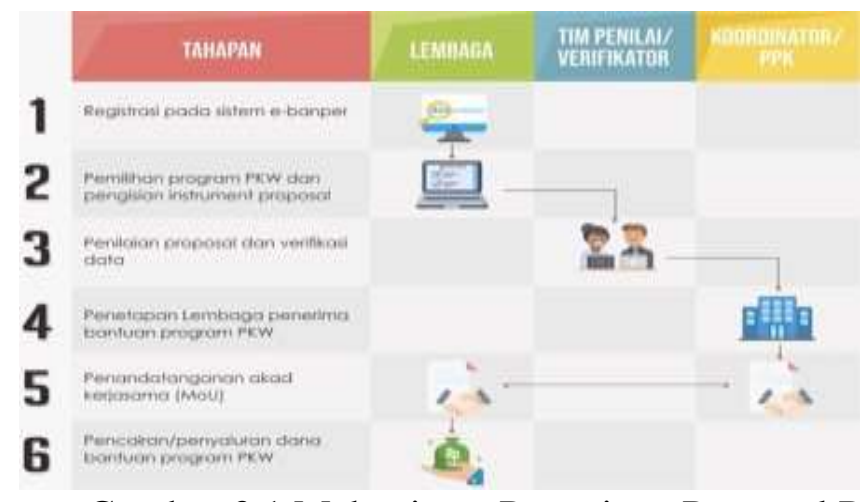

Gambar 3.1 Mekanisme Pengajuan Proposal Program PKW Sumber : (Perdirjen Pendidikan Vokasi No 02 Tahun 2020)

Dari gambar diatas terlihat alur pendaftaran yang disediakan oleh Direktorat Kursus dan Pelatihan sudah mengedepankan prinsip keterbukaan informasi dimana keterangan mengenai program, persyaratan serta lembaga pendidikan yang lulus seleksi dapat diakses informasinya oleh public melalui website https://banper.binsuslat.kemdikbud.go.id/

Sebaran lembaga pelaksana pada tahun 2020 telah dilakukan proses seleksi terhadap sekitar 1.100 proposal yang diterima, dengan 777 lembaga yang telah lolos seleksi dan ditetapkan sebagai pelaksana program dan diikuti oleh sebanyak 16.676 peserta didik (Direktorat Kursus dan Pelatihan, 2020). Penentuan lembaga yang memenuhi persyaratan dilakukan melalui tahapan penilaian proposal yang dikirimkan oleh lembaga baik secara daring maupun luring, yang telah disetujui oleh dinas pendidikan terkait. Proses penilaian proposal ini dilakukan langsung oleh Direktorat Kursus dan Pelatihan dengan melibatkan tim ahli.

\section{Model Kesesuaian Implementasi Program}

Manfaat program dapat terlihat salah satunya melalui implementasi yang berjalan dengan baik. Penulis menggunakan teori implementasi program dari David Korten.

600 AKSARA: Jurnal Ilmu Pendidikan Nonformal 
Model ini melihat implementasi kebijakan atau program sebagai cara untuk mempresentasikan layanan yang dilakukan oleh pemerintah kepada masyarakat. Dalam model kesesuaian ini proses implementasi yang terjadi dipandang sebagai sebuah proses kolaboratif antara birokrasi dengan kelompok sasaran yang menjadi tujuan pemerintah. Masyarakat dalam hal ini adalah sebagai focus utama sekali sekaligus pelaku utama dan bukan hanya sebagai pemanfaat. Sementara itu pemerintah memiliki peran lebih kepada fasilitator bukan lagi sebagai penyedia layanan dan manfaat gunanya adalah untuk menumbuhkan kemandirian di dalam masyarakat.

PROGRAM

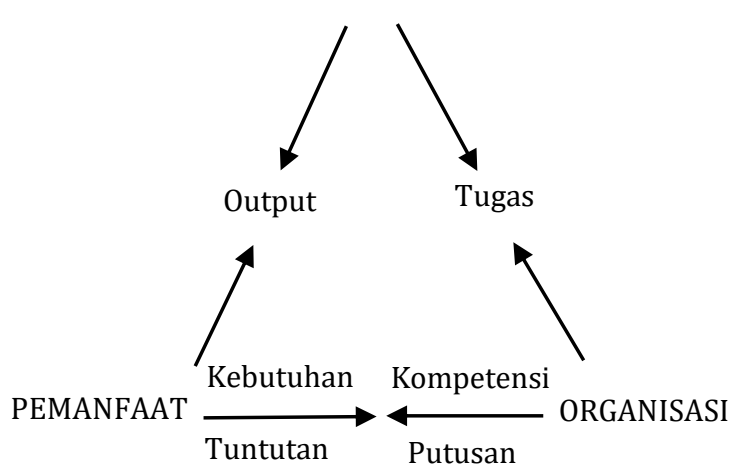

Gambar 3.2 Model Kesesuaian Implementasi Program David Korten (Haedar \& Tarigan, 2008)

\section{Program}

Pelaksanaan di LKP Karya Duta, dimulai pada tanggal 7 September 2020 setelah dana diterima pada tanggal 31 Agustus 2020 sebesar 150 juta rupiah. Setelah menerima dana, pihak lembaga langsung membelanjakan sebesar $10 \%$ dari anggaran untuk alat tulis kantor (atk) dan bahan-bahan habis pakai lainnya. Dari hasil wawancara, anggaran ini digunakan untuk atk sebesar Rp. 3.200.000,- dengan separuhnya adalah merupakan pembelanjaan alat pendukung protocol kesehatan seperti masker, hand sanitizer dan penutup wajah. Pembelian alat pendukung protocol kesehatan ini memang merupakan sebuah pengecualian dikarenakan saat ini sedang terjadi penyebaran virus Covid19 dimana kegiatan yang melibatkan masyarakat wajib mengikuti langkah yang telah ditentukan pemerintah. Selain itu juga pemanfaatan alokasi dana manajemen $10 \%$ juga digunakan untuk rapat koordinasi, proses rekrutmen peserta, honor pengelola dan instruktur serta koordinasi dengan dunia usaha.

Proses pembelajaran di LKP Karya Duta dimulai dengan pengenalan soft skill yang dibutuhkan dalam dunia usaha seperti etika, tata krama, penerjemahan permintaan klien, identifikasi data dalam bentuk digital, pemasaran, sampai pada pola kerja yang berdedikasi dan professional. 

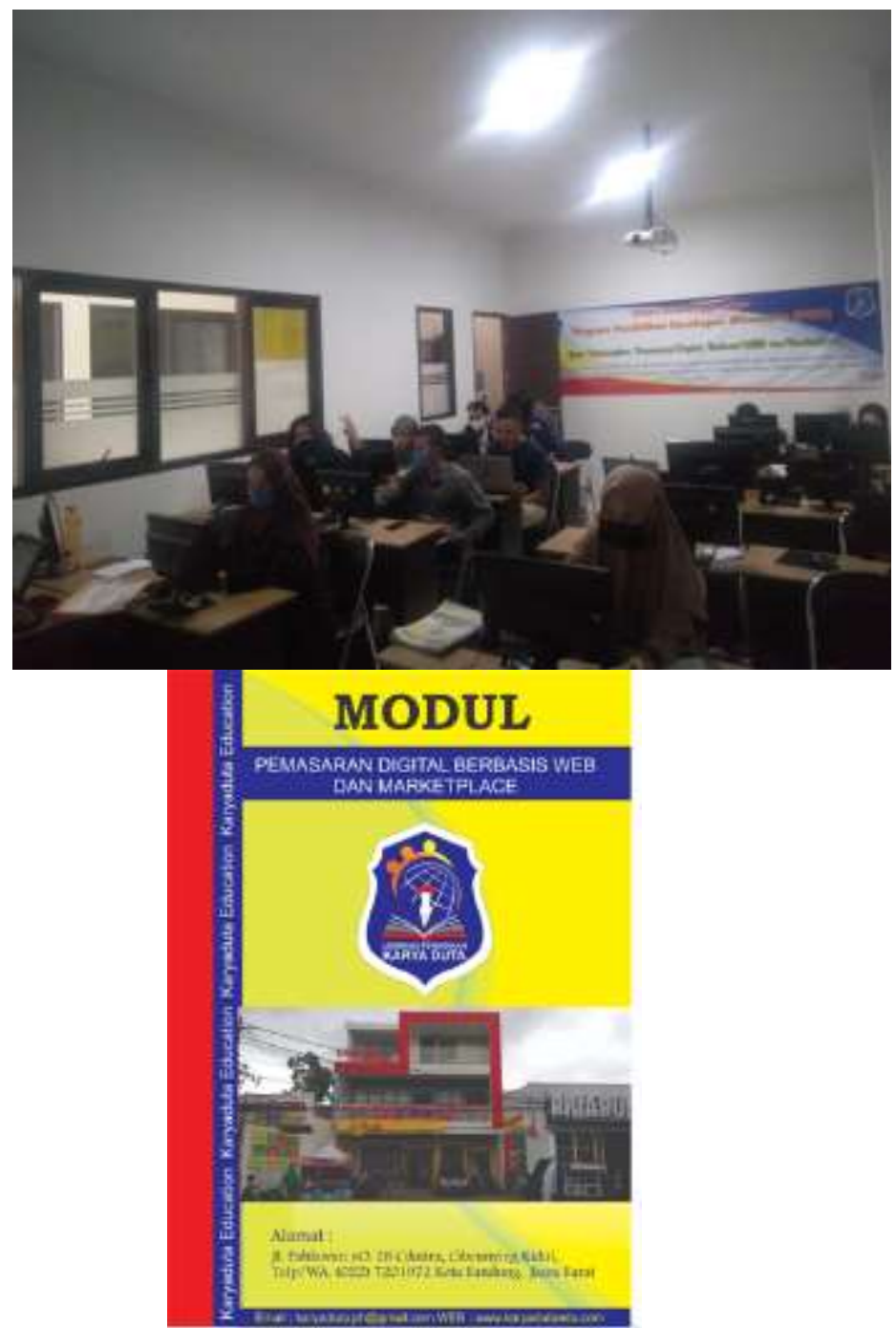

Gambar 3.3 Pembelajaran LKP Karya Duta

Sumber : LKP Karya Duta, 2021

Dari data yang diperoleh proses pembelajaran dilakukan selama periode September hingga Desember dengan total pembelajaran teori sebanyak 35 jam dengan 105 jam praktek. Menurut (Jones, 1994) diperlukan adanya pembuatan prosedur kerja yang jelas agar program dapat berjalan sesuai dengan rencana sehingga didapat hasil yang maksimal. Waktu pembelajaran tidak dilakukan setiap hari mengingat saat itu Covid-19 sedang mewabah.

Proses evaluasi adalah proses selanjutnya setelah para peserta selesai melakukan keseluruhan dari proses pembelajaran. Sesuai ketentuan yang tercantum di dalam Perdirjen Nomor 02 Tahun 2020 tentang program Pendidikan Kecakapan Wirausaha, kegiatan evaluasi ini berguna untuk mengetahui sejauh mana perkembangan didik dalam menyerap pembelajaran yang akan diberikan dan bagaimana nantinya perintisan usaha akan mulai dilakukan. Proses evaluasi ini pada beberapa lembaga dilakukan dengan melibatkan tempat uji kompetensi atau yang lebih dikenal dengan TUK, namun hal ini tidak diwajibkan mengingat keterbatasan

AKSARA: Jurnal Ilmu Pendidikan Nonformal 
alokasi anggaran. Sedangkan untuk LKP Karya Duta dalam penyelenggaraan program PKW ini, proses evaluasi dilakukan melalui ujian di lingkungan internal lembaga.

\section{Penerima Manfaat/Pemanfaat}

Berdasarkan hasil wawancara yang dilakuakan, proses rekrutmen calon peserta program yang dilakukan oleh lembaga, dalam hal ini dilakukan oleh LKP Karya Duta, banyak menggunakan jaringan alumni. Jaringan alumni yang dimaksud adalah para peserta program regular yang saat ini telah menyelesaikan studi pada lembaga tersebut. Jaringan alumni yang terdata secara konsisten akan sangat membantu dalam banyak hal, diantaranya adalah promosi mengenai adanya program ini yang dilakukan dari mulut ke mulut. Selain itu juga penggunaan media sosial dirasa sangat menbantu kedua lembaga dalam proses sosialisasi ini.

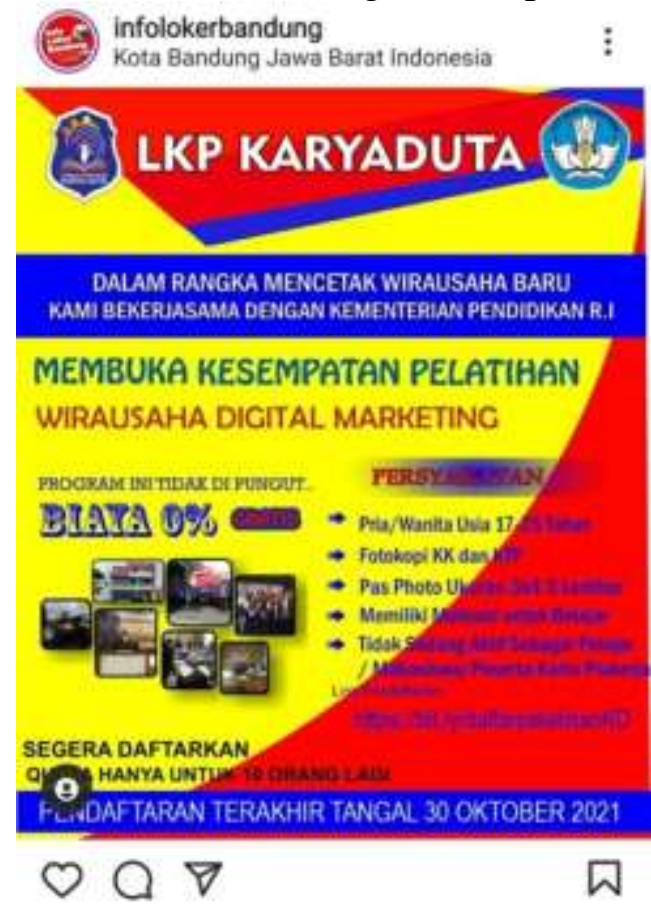

Gambar 3.4 Penggunaan Media Sosial sebagai Media Rekrutmen Sumber : LKP Karya Duta

Dari gambar diatas dapat disimpulkan bahwa terjadi proses komunikasi melalui media sosial dalam rangka perekrutan calon peserta didik. Dalam iklan tersebut sudah tercantum beberapa ketentuan dari dari program yang harus terlebih dahulu dipenuhi oleh calon peserta untuk kemudian dilakukan seleksi secara manual oleh pihak lembaga penyelenggara. Sudah jelas pula tercantum mengenai topik pelatihan, skema pembiayaan, serta jumlah peserta yang masih dapat diterima. Kejelasan penyampaian informasi sangat mempengaruhi pelaksanaan suatu program (Edward III, 1980).

Peserta didik program selaku penerima manfaat pada LKP Karya Duta mayoritas datang dari keluarga yang kurang mampu. Terlihat dari jenjang pendidikan terakhir yang ditempuh oleh sebagian besarnya merupakan alumni paket $\mathrm{C}$ meskipun ada yang dari paket B namun sudah pernah bekerja sebelumnya. Para peserta didik yang sudah 
pernah bekerja namun saat program dilangsungkan sedang tidak bekerja, dan ingin meningkatkan kompetensi serta memiliki kemauan untuk merintis usaha adalah termasuk mereka yang berhak mengikuti program ini. Hal ini menunujukkan bahwa semangat untuk maju dari peserta didik ini cukup besar meskipun tidak memiliki ijazah dari sekolah formal. Untuk usia peserta bervariasi antara kelahiran 1992 sampai dengan 2002 yang artinya termasuk dalam persyaratan yang diminta dalam ketentuan program PKW.

\section{Organisasi Pelaksana}

LKP Karya Duta sendiri berdiri sejak 17 tahun yang lalu dengan focus pembelajaran pada pendidikan luar sekolah. Adapun pendidikan luar sekolah yang dimaksud adalah program Kesetaraan paket A, B dan $\mathrm{C}$ selain itu juga menyelenggarakan program khusus dan pelatihan yang berfokus pada pendidikan bidang computer. Sebagai lembaga pendidikan yang focus pada pendidikan di luar sekolah LKP ini telah di akreditasi oleh BAN PNF (Badan Akreditasi Nasional Pendidikan Non Formal) dengan nilai A pada tahun 2019 yang lalu. Akreditasi ini menunjukkan bahwa konsistensi lembaga sejak 17 setahun yang lalu dan kiprahnya di bidang pendidikan nonformal sudah diakui secara resmi. Akreditasi bidang pendidikan nonformalsendiri mencakup delapan standar yaitu standar isi, standar kompetensi lulusan standar pendidik dan tenaga kependidikan, standar pengelolaan, standar pembiayaan, standar proses, standar sarana dan prasarana serta standar penilaian.

Dalam melaksanakan program PKW ini LKP Karya Duta mengadakan program keahlian Digital Marketing. Adapun jenis keahlian ini mencakup pembuatan website, pemasangan iklan pada platform besar seperti Google, Facebook dan lain-lain, serta keahlian membuat konten video serta desain produk. Sebagian dari program ini adalah merupakan program regular dari LKP Karya Duta yang memang fokus pada pengambangan bidang keahlian computer.

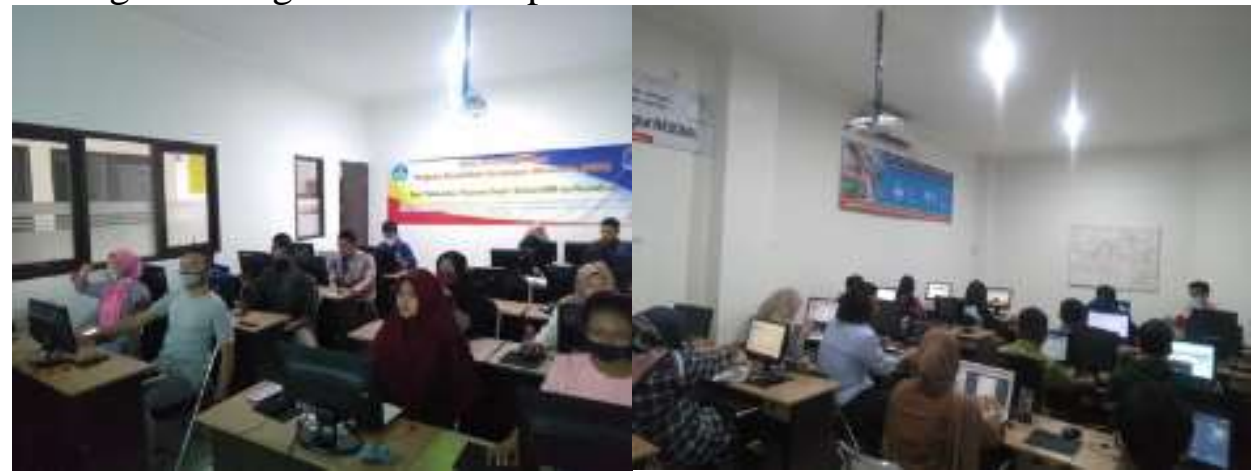

Gambar 3.5Fasilitas Sarana LKP Karya Duta

Sumber : (Penulis, 2021)

Dari gambar diatas, dapat dilihat bahwa sarana computer yang dimiliki oleh KPK Duta sudah sesuai dengan persyaratan yang diminta dalam petunjuk program PKW yaitu satu banding satu artinya satu peserta didik akan mendapat fasilitas satu buah computer. Hal ini juga ditunjang dengan prasarana berupa gedung dan ruangan yang cukup untuk menampung sejumlah siswa. Kelayakan sarana dan prasarana yang dimiliki. sangat penting mengingat materi yang akan diajarkan memerlukan keseriusan

AKSARA: Jurnal Ilmu Pendidikan Nonformal 
dan konsentrasi peserta didik yang mana akan sangat mengganggu apabila penggunaan computer harus dilakukan secara bergantian. Selain itu juga penggunaan computer satu dengan satu akan memudahkan para peserta didik apabila mengalami kesulitan dalam proses belajar ataupun praktek.

Adapun teori model kesesuaian dari David Korten, mensyaratkan ketiga unsur implementasi program diatas yang saling terkait dan menunjang keberhasilan pelaksanaan, yaitu :

\section{Kesesuaian antara program dengan pemanfaat}

Merupakan bentuk kesesuaian antara manfaat yang ditawarkan oleh program dengan kebutuhan penerima manfaat atau kelompok sasaran.

Dalam program PKW ini, terdapat persyaratan yang digunakan sebagai saringan awal dari calon peserta didik atau dalam hal ini penerima manfaat yaitu diantaranya, berada dalam rentang usia produktif, tidak memiliki penghasilan, dan merupakan masyarakat usia sekolah yang tidak sekolah. Kriteria seperti ini menjadi sasaran dari program PKW dengan tujuan agar calon peserta mendapatkan keterampilan atau peningkatan kompetensi yang sesuai dengan minat dan prospek usaha. Menurut Audy Shafa, salah satu peserta program pada LKP Karya Duta, sejak menyelesaikan pendidikan di SMA dirinya sudah mengirimkan lamaran kerja ke beberapa toko, supermarket di Kota Bandung namun belum juga mendapatkan panggilan bahkan untuk wawancara kerja. Dengan setelah mengetahui adanya program ini dari media sosial, dia dan beberapa rekan seangkatan mencoba mengikuti proses seleksi yang dilakukan oleh LKP Karya Duta karena memang membutuhkan pemasukan selain itu juga untuk menambah kompetensi pribadi. Ketentuan dalam program mengenai $30 \%$ pembelajaran teori yang berisi pendidikan karakter, pelatihan sesuai bidang keterampilan, pemasaran dan akses permodalan dan pengelolaan hasil, dirumuskan agar peserta dapat dibekali dengan soft skill yang akan sangat menunjang dalam menjalankan rintisan usaha. Demikian juga dalam ketentuan besaran jumlah bantuan modal rintisan usaha, yang telah diperhitungkan sedemikian rupa, menurut Audy sangat memudahkan peserta dalam belajar mengelola dan mengatur keuangan tentu saja dengan bimbingan dari pihak terkait. Dimana output yang diharapkan adalah dia dan rekan yang lain akan dapat membentuk rintisan2 usaha mandiri. Sehingga akan sangat membantu dalam menjalani usaha.

\section{Kesesuaian antara program dengan organisasi pelaksana}

Artinya, ketentuan yang tercantum dalam program yang akan dijalankan oleh organisasi pelaksana, dalam hal ini organisasi pelaksana harus mampu memenuhi persayaratan seperti sarana maupun prasarana sesuai dengan yang disyaratkan dalam ketentuan program.

Dalam program PKW ini, organisasi pelaksana yang dimaksud adalah lembaga pendidikan yang telah lulus seleksi dan dianggap memenuhi persyaratan sebagai penyelenggara program. Persyaratan yang harus dipenuhi oleh lembaga selain memiliki sarana prasaran yang memadai, juga harus memiliki mitra usaha, hal ini dimaksudkan agar nantinya lembaga dapat 
bekerjasama dengan mitra usaha dalam memberikan pembelajaran dan pelatihan, seperti penyusunan jadwal, silabus sampai pada system penilaian peserta. Berdasarkan wawancara dengan Wildan, selaku sekretaris program PKW di LKP Karya Duta, instruktur akan lebih mampu memberikan pelatihan karena memang terlibat langsung dalam proses kerja di lapangan. Dalam proses seleksi program PKW ini, dilakukan melalui proposal baik dalam bentuk digital maupun hardcopy, oleh pihak Direktorat Kursus dan Pelatihan. Selain itu, dalam penyampaian proposal juga dilakukan penilaian secara tidak langsung oleh dinas pendidikan setempat dalam bentuk penerbitan surat rekomendasi. Menurut bapak Kastum, Koordinator program PKW, ini dimaksudkan agar lembaga yang memiliki track record yang baguslah yang akan mendapat rekomendasi untuk penyelenggaraan program ini. Selain itu juga seleksi seperti ini dimaksudkan agar lembaga lain yang belum memenuhi persyaratan yang diminta untuk selalu memperbaiki kualitas lembaga, baik dari sisi manajemen, pembelajaran maupun dari sisi koordinasi dengan pihak-pihak terkait di daerah masing-masing.

\section{Kesesuaian antara penerima manfaat dengan organisasi pelaksana}

Merupakan kesesuaian antara syarat yang diputuskan organisasi untuk dapat memperoleh manfaat program dengan apa yang harus dilakukan atau yang harus dipenuhi oleh kelompok penerima manfaat.

Program PKW ini selain membutuhkan sarana dan prasarana yang memadai untuk mencapai tujuan, juga memerlukan ketepatan sasaran untuk mencapai tujuan dari program secara optimal. Sasaran yang berasal dari masyarakat yang tidak berpenghasilan akan membuat alur serta tujuan akhir program menjadi tepat, karena mereka memang membutuhkan bantuan dalam mendapatkan penghasilan, menurut bapak Kastum. Sasaran ini akan dapat diintervensi oleh organisasi pelaksana sesuai dengan yang dirumuskan dalam program. Artinya, sasaran ini nantinya akan merasakan hasil yang maksimal, berupa peningkatan kompetensi dan soft skill, pada saat program telah terlaksana secara komprehensif. Kesesuaian ini juga berguna untuk mencegah terjadinya tumpang tindih atau kesalahan dalam menentukan sasaran program. Ketika proses seleksi calon peserta telah dilaksanakan, sebagai bentuk tuntutan kesesuaian, seperti yang diinginkan dalam program ini, tahapan seleksi selanjutnya ada pada proses pembelajaran itu sendiri. Dimana instruktur dapat mengambil keputusan setelah melihat sejauhmana peserta dapat menerima dan menyerap materi serta pelatihan yang disampaikan selama program berlangsung. Nantinya lembaga akan dapat mengatur apakah dibutuhkan peralatan tambahan agar peserta tersebut semakin paham dengan materi yang diberikan.

Dari penjelasan terkait tiga kesesuaian unsur implementasi di atas dapat ditarik kesimpulan bahwa program PKW yang dilaksanakan oleh LKP Karya Duta telah terlaksana dengan baik dan sesuai dengan ketentuan yang berlaku. Selain itu juga unsur unsur yang terkandung dalam variable model kesesuaian implementasi program dari David Korten telah semuanya terpenuhi. Kesesuaian antara program dengan penerima

AKSARA: Jurnal Ilmu Pendidikan Nonformal 
manfaat terbukti dengan banyaknya masyarakat usia produktif yang mengikuti program dan akhirnya memiliki kompetensi serta dapat memulai rintisan usaha. Kesesuaian antara program dengan organisasi pelaksana juga dapat terpenuhi dengan baik ini terlihat dari penugasan penugasan yang terdapat dalam ketentuan program yang telah dipenuhi oleh LKP Karya Duta dalam rangka melaksanakan program PKW. Kesesuaian antara organisasi pelaksana dengan penerimaan manfaat dapat terlihat dari LKP Karya Duta melakukan seleksi terhadap calon calon peserta program di mana seleksi ini berguna untuk mengetahui pengetahuan dasar serta kemampuan dari dalam peserta didik, selain itu juga kesesuaian ini menunjukkan bahwa tuntutan dari para peserta didik agar dapat menjalan kan program dengan baik telah dipenuhi oleh LKP Karya Duta.

\section{SIMPULAN}

Dalam mengimplementasikan sebuah kebijakan kita harus mengetahui dan memahami dengan pasti apakah kebijakan yang di rumuskan dan dibuat sudah tepat sasaran dan mampu mengatasi permasalahan yang ada atau apakah permasalan tersebut mampu menanggulangi fenomena yang muncul. Selain itu dalam pelaksanaan kebijakan faktor lingkungan kebijakan juga harus mendapat perhatian yang serius. Dalam proses dalam upaya peningkatan kompetensi masyarakat usia produktif pemerintah sebagai perumus kebijakan dan Kementerian Pendidikan dan Kebudayaan dalam hal ini Direktorat Jenderal Pendidikan Vokasi sebagai pelaksana teknis harus bekerjasama dan memiliki pemahaman yang sinkron mengenai substansi dari kebijakan yang di rumuskan oleh pemerintah pusat. Kesamaan persepsi ini akan sangat diperlukan dalam menyusun pelaksanaan teknis yang berhubungan dengan cara penyelesaian masalah.

Pelaksanaan program PKW di LKP Karya Duta sudah berjalan cukup baik. Terlihat dari hasil wawancara yang menunjukkan antusiasme peserta, dengan didukung oleh organisasi pelaksana yang berhasil mencukupi kebutuhan sarana prasarana yang dibutuhkan, serta program yang memang tepat mengena pada sasaran dengan memberikan pembelajaran untuk peningkatan kompetensi dan modal untuk rintisan usaha. Serta hasil akhir yang menunjukkan bahwa lebih dari 95\% peserta program PKW telah berhasil menyelesaikan tahap pembelajaran dan saat ini sedang menjalani tahapan pendampingan perintisan usaha bersama dengan dinas setempat.

\section{DAFTAR PUSTAKA}

Agustina, T. S. (2015). Kewirausahaan Teori dan Penerapan pada Wirausaha dan UKM di Indonesia. Jakarta: Mitra Wacana Media.

BPS. (2020). Persentase Usia Muda (15-24 Tahun) Yang Sedang Tidak Sekolah, Bekerja Atau Mengikuti Pelatihan (Persen), 2018-2020. Retrieved January 26, 2021, from https://www.bps.go.id/indicator/6/1186/1/persentase-usia-muda-15-24-tahun-yangsedang-tidak-sekolah-bekerja-atau-mengikuti-pelatihan.html

Coombs, P., \& Manzoor, A. (1985). Memerangi Kemiskinan di Pedesaan dengan Pendidikan Nonformal. Jakarta: CV. Rajawali.

Creswell, J. W. (2019). Research Design ; Pendekatan Metode Kualitatif, Kuantitatif dan Campuran (4th ed.). Yogyakarta: Pustaka Pelajar.

Direktorat Kursus dan Pelatihan, T. U. (2020). Petunjuk Teknis : Bantuan Pemerintah 
Program Pendidikan Kecakapan Wirausaha (PKW). Jakarta: Tata Usaha Direktorat Kursus.

Eichhorst, W., Rodriguez-Planas, N., Schmidl, R., \& Zimmermann, K. (2015). A Road Map To Vocational Education and Training in Industrialized Countries. Industrial and Labor Relations Review, XX(X), 1-24. https://doi.org/10.1177/0019793914564963

Haedar, A., \& Tarigan, A. (2008). Artikulasi Konsep Implementasi Kebijakan: Perspektif, Model Dan Kriteria Pengukurannya. Jurnal Kebijakan Publik, 1.

Jones, C. O. (1994). Pengantar Kebijakan Publik (Public Policy). Jakarta: PT. Raja Grafindo Persada.

Miller, M. D. (1985). Principles and Philosophy for Educational Education. Ohio: The National Center of Research in Vocational Education, The Ohio University.

Minniti, M. (2008). The Role of Government Policy on Entrepreneurial Activity: Productive, Unproductive, or Destructive?. Entrepreneurship Theory and Practive. Texas: Baylor University.

Nugroho, R. (2014). Public Policy; Teori, Manajemen, Dinamika, Analisis, Konvergensi dan Kimia Kebijakan. Jakarta: Elex Media Komputindo.

Onstenk, J. (2003). Entrepreneurship and Vocational Education. European Educational Research Journal, 2(1), 74-89.

Rojewski, J. . (2009). A Conceptual Framework for Technical and Vocational Education and Training. Bonn: Springer.

Sudira, P. (2015). Pengaruh Strategi Pembelajaran, Gaya Belajar, Sarana Praktik, dan Media terhadap hasil Belajar Patiseri SMK se-Gerbang Kertasusila. Jurnal Pendidikan Vokasi, 5(1), 88-102.

Ulya, F. N. (2020, November). Pemerintah Kejar Target Rasio Wirausaha 3,9 Persen Tahun 2024.

Van Meter, D., \& Van Horn, C. (1975). The Policy Implementation Process: A Conceptual Framework. London: Sage.

Westra, P. (1989). Ensiklopedi Administrasi. Jakarta: Gunung Agung.

Wibawa, S. (2002). Evaluasi Kebijakan Publik. Jakarta: Raja Grafindo Persada. 